\title{
Polyphasic taxonomic study of strain CCM 2783 resulting in the description of Arthrobacter stackebrandtii sp. nov.
}

Correspondence

Ludmila Tvrzová

lida@sci.muni.cz

\author{
Ludmila Tvrzová, ${ }^{1}$ Peter Schumann, ${ }^{2}$ Cathrin Spröer, ${ }^{2}$ Ivo Sedláček, ${ }^{3}$ \\ Susanne Verbarg, ${ }^{2}$ Reiner M. Kroppenstedt ${ }^{2}$ and Zdena Páčová ${ }^{3}$ \\ ${ }^{1,3}$ Department of Microbiology, Faculty of Science ${ }^{1}$ and CCM - Czech Collection of \\ Microorganisms ${ }^{3}$, Masaryk University Brno, Tvrdého 14, 60200 Brno, Czech Republic \\ ${ }^{2}$ DSMZ - Deutsche Sammlung von Mikroorganismen und Zellkulturen, Mascheroder Weg 1b, \\ 38124 Braunschweig, Germany
}

\begin{abstract}
Strain CCM 2783, previously classified as representing Arthrobacter aurescens, was subjected to a polyphasic taxonomic study. 16S rRNA gene sequence analysis and chemotaxonomic characteristics such as peptidoglycan type $A 3 \alpha$ Lys-Ala $a_{2}$, major menaquinone $M K-9\left(H_{2}\right)$ and fatty acid composition confirmed assignment of the strain to the genus Arthrobacter. The results of phylogenetic analysis, DNA-DNA relatedness experiments and physiological and chemotaxonomic characteristics indicate that CCM 2783 differs from its nearest phylogenetic relative Arthrobacter psychrolactophilus and from other recognized Arthrobacter species. Therefore, a novel species, Arthrobacter stackebrandtii sp. nov., is proposed with the type strain CCM $2783^{\top}\left(=\right.$ DSM $\left.16005^{\top}\right)$.
\end{abstract}

Strain CCM 2783 was isolated from poultry litter and identified on the basis of phenotypic features as representing Arthrobacter aurescens (Antheunisse \& Vonkeman, 1975). During the course of a taxonomic study of arthrobacters, we found that the strain differed from the type strain of A. aurescens. In this study, we report the taxonomic characterization of strain CCM 2783 and propose to classify it as representing a novel species of the genus Arthrobacter, Arthrobacter stackebrandtii sp. nov.

Strain CCM 2783 and the closely related type strain Arthrobacter psychrolactophilus DSM $15612^{\mathrm{T}}$ were routinely cultivated on tryptone soy medium (Oxoid) at $28^{\circ} \mathrm{C}$. Standardized methods as described by Smibert \& Krieg (1994) and the API CORYNE, API ZYM and Biolog systems were used for phenotypic characterization of the strains. The commercial kits were applied according to the manufacturer's instructions.

Genomic DNA extraction, PCR-mediated amplification of the 16S rRNA gene sequence and purification of PCR products were carried out as described by Rainey et al.

Published online ahead of print on 5 November 2004 as DOI 10.1099/ ijs.0.63428-0.

The GenBank/EMBL/DDBJ accession number for the 16S rRNA gene sequence of strain CCM $2783^{\top}$ is AJ640198.

An extended neighbour-joining tree based on 16S rRNA gene sequence analysis is available as a supplementary figure in IJSEM Online.
(1996). Purified PCR products were sequenced with the CEQ DTCS Quick Start kit (Beckman Coulter) as directed in the manufacturer's protocol. The CEQ 8000 Genetic Analysis System was used for electrophoresis of the sequence reaction products.

The ae2 editor (Maidak et al., 1999) was used to align the 16S rRNA gene sequence of strain CCM 2783 against those of representatives of the main bacterial lineages available from the public databases. Evolutionary distances were calculated by the method of Jukes \& Cantor (1969). Phylogenetic dendrograms were constructed using the neighbourjoining algorithms (De Soete, 1983). Bootstrap analysis was used to evaluate the tree topology by performing 1000 resamplings (Felsenstein, 1993). DNA for DNA-DNA hybridization experiments was isolated by using a French pressure cell and purified by chromatography on hydroxyapatite as described by Cashion et al. (1977). DNA-DNA reassociation was performed under optimal conditions $(2 \times$ SSC at $67^{\circ} \mathrm{C}$ ) and recorded using a Gilford 2600 spectrophotometer (Huß et al., 1983; Jahnke, 1992). Automated ribotyping was carried out using the RiboPrinter microbial characterization system (Qualicon; DuPont) and EcoRI and $P v u \mathrm{II}$ to generate restriction fragments.

The peptidoglycan structure was determined by using total $\left(4 \mathrm{M} \mathrm{HCl}, 100^{\circ} \mathrm{C}, 16 \mathrm{~h}\right.$ ) and partial $\left(4 \mathrm{M} \mathrm{HCl}, 100^{\circ} \mathrm{C}\right.$, $45 \mathrm{~min}$ ) hydrolysates of purified cell walls according to Schleifer (1985). Amino acids and peptides were separated by two-dimensional ascending TLC on cellulose plates with 
the solvent systems of Schleifer \& Kandler (1972). The molar ratio of the amino acids was determined by GC as described by MacKenzie (1987). Menaquinones were extracted according to Collins et al. (1977) and analysed by HPLC (Groth et al., 1996). Fatty acids were extracted and analysed following the instructions of the Microbial Identification System operating manual (MIDI, 1999).

Phylogenetic analysis based on the almost complete $16 \mathrm{~S}$ rRNA gene sequence (1518 nt) confirmed that strain CCM 2783 belongs to the genus Arthrobacter and that it was distinct from $A$. aurescens (Fig. 1; an extended dendrogram is available as Supplementary Fig. A in IJSEM Online). The highest binary 16S rRNA gene sequence similarity was found to the type strain of Arthrobacter psychrolactophilus DSM $15612^{\mathrm{T}}(98 \cdot 1 \%)$. The similarity to the recently described Arthrobacter russicus GTC $863^{\mathrm{T}}$ (Li et al., 2004) was 95.3\%. DNA-DNA relatedness between strain CCM 2783 and A. psychrolactophilus DSM $15612^{\mathrm{T}}$ was only $18 \cdot 7 \%$ $(24.3 \%$ after repetition), which is clearly below the $70 \%$ considered to be the threshold value for the delineation of genomic species (Wayne et al., 1987). The RiboPrint patterns of strain CCM 2783 (generated by EcoRI and $P v u I I)$ were different from those of the type strain of $A$. psychrolactophilus (data not shown).

Cell wall analysis revealed that lysine is the diagnostic diamino acid in the peptidoglycan of strain CCM 2783. Peptidoglycan type A $3 \alpha$ (according to Schleifer \& Kandler, $1972)$ and the major menaquinone MK- $9\left(\mathrm{H}_{2}\right)$ place strain CCM 2783 within the 'Arthrobacter globiformis group' of the genus Arthrobacter (Stackebrandt \& Schumann, 2000). The peptidoglycan composition and menaquinone pattern allow differentiation of CCM 2783 from A. psychrolactophilus DSM $15612^{\mathrm{T}}$ and related species.

The peptidoglycan of strain CCM 2783 contained an $\mathrm{Ala}_{2}$ interpeptide bridge and the alpha-carboxyl group of Dglutamic acid at position 2 of the peptide subunit was replaced by D-alanine amide. Analysis of the peptidoglycan structure of $A$. psychrolactophilus DSM $15612^{\mathrm{T}}$ revealed type $\mathrm{A} 3 \alpha$ with a Thr-Ala 3 interpeptide bridge, type A11.28 according to the DSMZ catalogue of strains (DSMZ, 2001). The presence of threonine in the interpeptide bridge linked to the lysine residue was supported by the occurrence of the characteristic stable peptide Lys-Thr in the total peptidoglycan hydrolysate. Consequently, only reduced amounts of lysine and threonine could be detected after total hydrolysis of the peptidoglycan. This is in agreement with the relatively small amount of threonine in the peptidoglycan of the A. psychrolactophilus type strain reported by LovelandCurtze et al. (1999). The presence of threonine in the interpeptide bridge was also reported in the phylogenetic neighbours of A. psychrolactophilus, Arthrobacter polychromogenes, Arthrobacter oxydans, Arthrobacter chlorophenolicus and Arthrobacter sulfonivorans (Keddie et al., 1986; Kodama et al., 1992; Westerberg et al., 2000; Borodina et al., 2002) and also of A. aurescens (Keddie et al., 1986). The $\mathrm{Ala}_{2}$ interpeptide bridge distinguishes CCM 2783 from all these related species and also from $A$. aurescens, to which this strain was affiliated by Antheunisse \& Vonkeman (1975).

Along with the major menaquinone MK-9 $\left(\mathrm{H}_{2}\right)$, strain CCM 2783 contained MK-10 $\left(\mathrm{H}_{2}\right)$ as a minor component and a small amount of MK-11( $\left.\mathrm{H}_{2}\right)$. The strain differed in its menaquinone pattern from A. psychrolactophilus DSM $15612^{\mathrm{T}}$ (Table 1) and from A. aurescens, which was reported to possess predominant menaquinone $\mathrm{MK}-9\left(\mathrm{H}_{2}\right)$ and minor amounts of MK-8 $\left(\mathrm{H}_{2}\right)$, MK-7 $\left(\mathrm{H}_{2}\right)$ and MK-9 (Collins \& Jones, 1981).

The cellular fatty acid content of strain CCM 2783 was as follows (only values $>1 \%$ are reported): anteiso- $\mathrm{C}_{15: 0}$, $48 \cdot 1 \%$; anteiso- $\mathrm{C}_{17: 0}, 14 \cdot 4 \%$; iso- $\mathrm{C}_{14: 0}, 1 \cdot 84 \%$; iso- $\mathrm{C}_{15: 0}$,

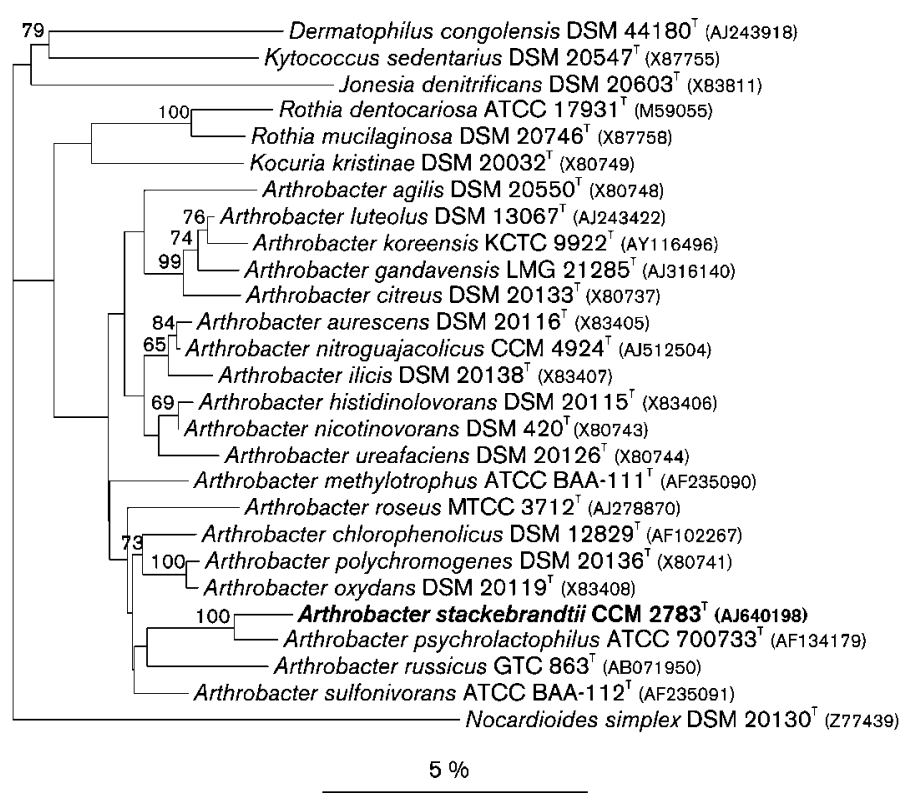

Fig. 1. Neighbour-joining tree based on 16S rRNA gene sequence analysis showing the phylogenetic position of $A$. stackebrandtii sp. nov. CCM $2783^{\top}$. The sequences of members of the Actinobacteria were used to root the dendrogram. Bootstrap values greater than $60 \%$ are shown at branching points. Bar, 5 nucleotide substitutions per 100 nucleotides. An extended version of this tree is available as supplementary material in IJSEM Online. 
Table 1. Characteristics used to distinguish Arthrobacter stackebrandtii sp. nov. CCM $2783^{\top}$ and A. psychrolactophilus DSM $15612^{\top}$

+ , Positive; -, negative.

\begin{tabular}{|c|c|c|}
\hline Characteristic & $\begin{array}{l}\text { A. stackebrandtii } \\
\text { CCM } 2783^{\mathrm{T}}\end{array}$ & $\begin{array}{l}\text { A. psychrolactophilus } \\
\text { DSM } 15612^{\mathrm{T}}\end{array}$ \\
\hline Growth at $\mathrm{pH} 9 \cdot 1$ & + & - \\
\hline Nitrate reduction & + & - \\
\hline Urease & + & - \\
\hline$\beta$-Glucuronidase & - & + \\
\hline$\alpha$-Glucosidase & - & + \\
\hline Aesculin hydrolysis & - & + \\
\hline \multicolumn{3}{|l|}{ Utilization of: } \\
\hline$\alpha$-Cyclodextrin & + & - \\
\hline Tween 40 & + & - \\
\hline$N$-Acetyl-D-mannosamine & - & + \\
\hline L-Arabinose & + & - \\
\hline L-Fucose & + & - \\
\hline D-Melezitose & - & + \\
\hline Methyl $\alpha$-D-galactoside & + & - \\
\hline Methyl $\beta$-D-glucoside & - & + \\
\hline Stachyose & + & - \\
\hline L-Asparagine & + & - \\
\hline Uridine & + & - \\
\hline Peptidoglycan type & L-Lys-L-Ala 2 & L-Lys-L-Thr-L-Ala 3 \\
\hline Menaquinones (\%) & $\begin{array}{r}\left.\text { MK-9 }\left(\mathrm{H}_{2}\right), \text { MK-10( } \mathrm{H}_{2}\right) \\
\operatorname{MK}-11\left(\mathrm{H}_{2}\right)(62: 24: 5)\end{array}$ & $\begin{array}{r}\text { MK-9 }\left(\mathrm{H}_{2}\right), \text { MK-8 }\left(\mathrm{H}_{2}\right) \\
\operatorname{MK}-10\left(\mathrm{H}_{2}\right)(85: 6: 2)\end{array}$ \\
\hline
\end{tabular}

$14 \cdot 2 \%$; iso- $\mathrm{C}_{16: 0}, 16 \cdot 0 \%$; iso- $\mathrm{C}_{17: 0}, 3 \cdot 5 \% ; \mathrm{C}_{16: 0}, 1 \cdot 4 \%$. These data are in agreement with fatty acid profiles of members of the genus Arthrobacter. The fatty acid profile of strain CCM 2783 differs from that of A. psychrolactophilus DSM $15612^{\mathrm{T}}$ and from A. aurescens CCM $1649^{\mathrm{T}}$ by higher proportions of iso- $\mathrm{C}_{15: 0}$ and iso- $\mathrm{C}_{16: 0}$ and a lower proportion of anteiso- $\mathrm{C}_{15: 0}$ (Loveland-Curtze et al., 1999; Kotoučková et al., 2004).

Strain CCM 2783 is additionally differentiated from its closest relative A. psychrolactophilus DSM $15612^{\mathrm{T}}$ on the basis of a number of physiological and biochemical characteristics (Table 1). Additional phenotypic characteristics of strain CCM 2783 are given in the species description below.

\section{Description of Arthrobacter stackebrandtii sp. nov.}

Arthrobacter stackebrandtii (sta.cke.brand'ti.i. N.L. gen. masc. n. stackebrandtii of/from Stackebrandt, named in honour of Erko Stackebrandt for his pioneering contributions to our insight into the phylogenetic structure of the suborder Micrococcineae and of the genus Arthrobacter in particular).

Cells are irregular club-shaped rods showing a rodcoccus cycle, $0 \cdot 6-1 \times 1-3 \mu \mathrm{m}$, occurring in pairs as typical $\mathrm{V}$-forms. Gram-positive, non-motile and non-acid-fast, non-spore-forming. Growth occurs at $4-30{ }^{\circ} \mathrm{C}$. Growth occurs over a $\mathrm{pH}$ range $5 \cdot 7-9 \cdot 1$ and in the presence of $5 \% \mathrm{NaCl}$. Obligately aerobic. Positive for catalase, urease and pyrazinamidase. Negative for oxidase, $\beta$-glucuronidase, $\beta$-galactosidase, $\alpha$-glucosidase, $N$-acetyl- $\beta$-glucosaminidase and pyrrolidonyl arylamidase. Nitrate is reduced to nitrite. Nitrite is not reduced; Tween 80 and aesculin are not hydrolysed. Starch and gelatin are hydrolysed. Acid production is negative from glucose, ribose, xylose, mannitol, maltose, lactose, sucrose and glycogen. The following compounds are utilized (Biolog system): $\alpha$-cyclodextrin, dextrin, Tween 40, L-arabinose, D-arabitol, arbutin, Dcellobiose, D-fructose, L-fucose, D-galactose, $\alpha$-D-glucose, $\alpha$-D-lactose, lactulose, maltose, maltotriose, D-mannose, Dmelibiose, methyl $\alpha$-D-galactoside, methyl $\beta$-D-galactoside, palatinose, D-psicose, D-raffinose, D-ribose, salicin, stachyose, sucrose, $\mathrm{D}$-trehalose, turanose, $\mathrm{D}$-xylose, $\beta$-ketovaleric acid, methyl pyruvate, pyruvic acid, L-asparagine, glycerol, adenosine, inosine, thymidine and uridine. Negative reactions (Biolog) were observed with $\beta$-cyclodextrin, glycogen, inulin, mannan, Tween $80, N$-acetyl-D-glucosamine, $\mathrm{N}$-acetyl-D-mannosamine, amygdalin, D-galacturonic acid, gentiobiose, D-gluconic acid, meso-inositol, D-melezitose, 3 -methyl glucose, methyl $\alpha$-D-glucoside, methyl $\beta$-Dglucoside, methyl $\alpha$-D-mannoside, L-rhamnose, sedoheptulosan, D-sorbitol, xylitol, $\beta$-hydroxybutyric acid, $\gamma$-hydroxybutyric acid, $p$-hydroxyphenylacetic acid, $\alpha$ ketoglutaric acid, lactamide, D-lactic acid methyl ester, 
D-malic acid, monomethyl succinate, propionic acid, succinamic acid, succinic acid, $N$-acetylglutamic acid, alaninamide, D-alanine, L-alanine, L-alanyl glycine, Lglutamic acid, glycyl L-glutamic acid, L-pyroglutamic acid, putrescine, 2,3-butanediol, adenosine 5'-monophosphate, uridine 5'-monophosphate, fructose 6-phosphate, glucose 1-phosphate, glucose 6-phosphate and DL-glycerophosphate.

The type strain, CCM $2783^{\mathrm{T}}\left(=\mathrm{DSM} 16005^{\mathrm{T}}\right)$, was isolated from poultry litter.

\section{Acknowledgements}

This paper is dedicated to Erko Stackebrandt on the occasion of his 60th birthday. We are grateful to $\mathrm{H}$. Trüper, University of Bonn, Germany, for his help with the Latin construction of the species epithet. We also thank A. Vester, I. Kramer, G. Pötter and A. Frühling (DSMZ) for excellent technical assistance.

\section{References}

Antheunisse, J. \& Vonkeman, H. (1975). Identification and flagellation of coryneform bacteria from poultry litter. Can J Microbiol 21, 1798-1802.

Borodina, E., Kelly, P. D., Schumann, P., Rainey, F. A., Ward-Rainey, N. L. \& Wood, A. P. (2002). Enzymes of dimethylsulfone metabolism and the phylogenetic characterization of the facultative methylotrophs Arthrobacter sulfonivorans sp. nov., Arthrobacter methylotrophus sp. nov., and Hyphomicrobium sulfonivorans sp. nov. Arch Microbiol 177, 173-183.

Cashion, P., Holder-Franklin, M. A., McCully, J. \& Franklin, M. (1977). A rapid method for the base ratio determination of bacterial DNA. Anal Biochem 81, 461-466.

Collins, M. D. \& Jones, D. (1981). Distribution of isoprenoid quinone structural types in bacteria and their taxonomic implications. Microbiol Rev 45, 316-354.

Collins, M. D., Pirouz, T., Goodfellow, M. \& Minnikin, D. E. (1977). Distribution of menaquinones in actinomycetes and corynebacteria. J Gen Microbiol 100, 221-230.

De Soete, G. (1983). A least squares algorithm for fitting additive trees to proximity data. Psychometrika 48, 621-626.

DSMZ (2001). Catalogue of Strains, 7th edn. Braunschweig: DSMZ.

Felsenstein, J. (1993). PHYLIP (Phylogeny Inference Package), version 3.5.1. Distributed by the author. Department of Genetics, University of Washington, Seattle, USA.

Groth, I., Schumann, P., Weiss, N., Martin, K. \& Rainey, F. A. (1996). Agrococcus jenensis gen. nov., sp. nov., a new genus of actinomycetes with diaminobutyric acid in the cell wall. Int J Syst Bacteriol 46, 234-239.

Huß, V. A. R., Festl, H. \& Schleifer, K. H. (1983). Studies on the spectrophotometric determination of DNA hybridization from renaturation rates. Syst Appl Microbiol 4, 184-192.

Jahnke, K. D. (1992). Basic computer program for evaluation of spectroscopic DNA renaturation data from GILFORD System 2600 spectrometer on a PC/XT/AT type personal computer. J Microbiol Methods 15, 61-73.
Jukes, T. H. \& Cantor, C. R. (1969). Evolution of protein molecules. In Mammalian Protein Metabolism, vol. 3, pp. 21-132. Edited by H. N. Munro. New York: Academic Press.

Keddie, R. M., Collins, M. D. \& Jones, D. (1986). Genus Arthrobacter Conn and Dimmick 1947, 300 ${ }^{\mathrm{AL}}$. In Bergey's Manual of Systematic Bacteriology, vol. 2, pp. 1288-1301. Edited by P. H. A. Sneath, N. S. Mair, M. E. Sharpe \& J. G. Holt. Baltimore: Williams \& Wilkins.

Kodama, Y., Yamamoto, H., Amano, N. \& Amachi, T. (1992). Reclassification of two strains of Arthrobacter oxydans and proposal of Arthrobacter nicotinovorans sp. nov. Int J Syst Bacteriol 42, 234-239.

Kotoučková, L., Schumann, P., Durnová, E., Spröer, C., Sedláček, I., Neča, J., Zdráhal, Z. \& Němec, M. (2004). Arthrobacter nitroguajacolicus sp. nov., a novel 4-nitroguaiacol-degrading actinobacterium. Int J Syst Evol Microbiol 54, 773-777.

Li, Y., Kawamura, Y., Fujiwara, N., Naka, T., Liu, H., Huang, X., Kobayashi, K. \& Ezaki, T. (2004). Rothia aeria sp. nov., Rhodococcus baikonurensis sp. nov. and Arthrobacter russicus sp. nov., isolated from air in the Russian space laboratory Mir. Int J Syst Evol Microbiol 54, 827-835.

Loveland-Curtze, J., Sheridan, P. P., Gutshall, K. R. \& Brenchley, J. E. (1999). Biochemical and phylogenetic analyses of psychrophilic isolates belonging to the Arthrobacter subgroup and description of Arthrobacter psychrolactophilus sp. nov. Arch Microbiol 171, 355-363.

MacKenzie, S. L. (1987). Gas chromatographic analysis of amino acids as the $N$-heptafluorobutyryl isobutyl esters. J Assoc Off Anal Chem 70, 151-160.

Maidak, B. L., Cole, J. R., Parker, C. T., Jr \& 11 other authors (1999), A new version of the RDP (Ribosomal Database Project). Nucleic Acids Res 27, 171-173.

MIDI (1999). Sherlock Microbial Identification System, Operating Manual, version 3.0. Newark, DE: MIDI, Inc.

Rainey, F. A., Ward-Rainey, N., Kroppenstedt, R. M. \& Stackebrandt, E. (1996). The genus Nocardiopsis represents a phylogenetically coherent taxon and a distinct actinomycete lineage; proposal of Nocardiopsaceae fam. nov. Int J Syst Bacteriol 46, 1088-1092.

Schleifer, K. H. (1985). Analysis of the chemical composition and primary structure of murein. Methods Microbiol 18, 123-156.

Schleifer, K. H. \& Kandler, O. (1972). Peptidoglycan types of bacterial cell walls and their taxonomic implications. Bacteriol Rev 36, 407-477.

Smibert, R. M. \& Krieg, N. R. (1994). Phenotypic characterization. In Methods for General and Molecular Bacteriology, pp. 607-654. Edited by P. Gerhardt. Washington, DC: American Society for Microbiology.

Stackebrandt, E. \& Schumann, P. (2000). Introduction to the taxonomy of Actinobacteria. In The Prokaryotes, 3rd edn. New York: Springer. http://link.springer-ny.com/link/service/books/10125/ tocs.htm

Wayne, L. G., Brenner, D. J., Colwell, R. R. \& 9 other authors (1987). Report of the ad hoc committee on reconciliation of approaches to bacterial systematics. Int J Syst Bacteriol 37, 463-464.

Westerberg, K., Elväng, A. M., Stackebrandt, E. \& Jansson, J. K. (2000). Arthrobacter chlorophenolicus sp. nov., a new species capable of degrading high concentrations of 4-chlorophenol. Int J Syst Evol Microbiol 50, 2083-2092. 